\title{
Organizational Strategic Approach towards Work Life Balance of Women in India
}

\author{
Sonia Delrose Noronha, ${ }^{1} \&$ P. S. Aithal ${ }^{2}$ \\ ${ }^{1,}$ Research Scholar, Department of Management, Rayalaseema University, \\ Kurnool -518007, Andhra Pradesh, India. \\ ${ }^{1,2}$ Srinivas Institute of Management Studies, Pandeshwar, Mangaluru -575 001, India \\ E-Mail: soniadelrose@gmail.com
}

Type of the Paper: Research Paper.

Type of Review: Peer Reviewed.

Indexed in: OpenAIRE.

DOI: http://dx.doi.org/10.5281/zenodo.810349.

Google Scholar Citation: IJMTS

\section{How to Cite this Paper:}

Noronha, Sonia Delrose., \& Aithal, P. S. (2017). Organizational Strategic Approach towards Work Life Balance of Women in India. International Journal of Management, Technology, and Social Sciences (IJMTS), 2(1), 18-24.

DOI: http://dx.doi.org/10.5281/zenodo.810349.

International Journal of Management, Technology, and Social Sciences (IJMTS) A Refereed International Journal of Srinivas University, India.

(C) With Authors.

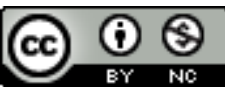

This work is licensed under a Creative Commons Attribution-Non Commercial 4.0 International License subject to proper citation to the publication source of the work.

Disclaimer: The scholarly papers as reviewed and published by the Srinivas Publications (S.P.), India are the views and opinions of their respective authors and are not the views or opinions of the SP. The SP disclaims of any harm or loss caused due to the published content to any party. 


\title{
Organizational Strategic Approach towards Work Life Balance of Women in India
}

\author{
Sonia Delrose Noronha, ${ }^{1} \&$ P. S. Aithal $^{2}$ \\ ${ }^{1,}$ Research Scholar, Department of Management, Rayalaseema University, \\ Kurnool -518007, Andhra Pradesh, India. \\ ${ }^{1,2}$ Srinivas Institute of Management Studies, Pandeshwar, Mangaluru -575 001, India \\ E-Mail: soniadelrose@gmail.com
}

\begin{abstract}
With the increase in education and awareness relating to women empowerment there is a considerable increase in the number of working women in different sectors. Ever-changing dynamic environment and economic conditions has pressurized the organizations to perform or perish. This in turn has created an unseen pressure on the employees. Career and personal life are the two aspects considered important by employees, the success of which requires major attention. The major challenge for women is to balance the demands and the requirements of career and family. The various aspects like socio demographic conditions, work stress, impact of work on personal life negatively affects the personal life and career advancement creating a glass ceiling for women employees. It is seen that in the absence of proper work-life balance policies and practice result in work-life conflict. This can be seen in the form of increased absenteeism, high attrition, low recognition and job satisfaction. There are initiatives taken by the organizations and the government but the question is if the initiatives taken are adequate and are actually benefitting the women employees. This paper reviews the work-life balance initiatives adopted by employers in different organizations. An attempt is also made to find the challenges undergone by the organizations in providing such measures to the women employees. The sources referred for this purpose includes various published research papers on internet sites, magazines, doctoral thesis, newspapers etc.
\end{abstract}

Keywords: Work-life balance, Glass ceiling, Work-life conflict, Absenteeism, Attrition, Job satisfaction.

\section{INTRODUCTION :}

In this ever-changing globalized competitive business world, work-life balance has become a matter of concern for researchers and organizations. Organizations need to be aware of the changing requirements and demand of the women employees at home and at work. Women are facing various issues and challenges because of increased responsibilities at work and personal life. To add on to its traditions and prejudice towards women creates a glass ceiling preventing women from advancing in their career [1]. This diversified lifestyle and changing work needs have compelled employers to focus on work life balance. Employers now give attention towards work life and personal life. It has become difficult for women to strike a balance between work and life. Work-life imbalance adversely affects the employees, their immediate families, organizations and the society at large. Appropriate coping up strategies should be adopted to manage the work demand and family demand. This will motivate the employees, increase satisfaction, commitment and productivity of the employees. Moreover, it will help in reducing the absenteeism and labour turnover. However, in India, the academic attempt to provide a complete picture of worklife balance programmes and benefits provided by various organisations seems to be very little. 


\section{MEANING AND SCOPE :}

Work life balance is the process of minimizing the role conflict of a person by maintaining his perceptions about work and his personal time and family welfare. Work life balance can be defined as the perception of an employee to maintain and integrate multiple domains of personal, time, family care and work with minimum role conflict [2]. Work life balance can be different to different people depending upon the different stages of life. It basically includes the problems of exhaustion and lack of time. Research shows that failure to achieve a satisfactory balance of effort is directly connected to lack of energy to fulfill personal commitments and lack of control over the workload. The imbalance here leads to consequences such as fatigue, poor quality of life and most importantly poor performance. Work life balance is the relationship between personal commitments and work and its impact on one another. The present study examines the innovative and current work-life balance policies and practices implemented and practiced by various Indian Companies. With the change in the workforce and the increase in the number of working women, dual earner and nuclear families the need for the employees to balance their work and personal life has also increased. Moreover, women still take the major responsibility of childcare and domestic chores, long hours work culture and lack of flexible work provision creates a disadvantageous situation for women than men. Women are unable to put in the required number of hours to advance their careers. Considering this requirement along with the intention to provide better quality of life and retention of efficient talented employees, companies are now providing various work-life programmes. Since Industrialization organizations have shown concern about their employees by formulating welfare policies like healthy working environment, safety, and securities. Post-war era has also evidenced increase of governmentmandated provisions offered to employees such as health insurance, social security measures like pension plan and also disability protection plan such as workers compensation in case of accidents and disease highlighting the notion of obligation of employers towards employees to provide social security to employee's families [3].

In the present study, an effort has been made to identify and reveal the present status and benefits of work-life balance programmes provided by various Indian Organizations and its future challenges. This study is based on the secondary data derived from literature review. As women still do the majority of childcare and domestic work, a lack of flexible working provision and a long-hours culture will disadvantage more women than men, as they will be unable to put in the hours required to advance their careers.

\subsection{Methodology}

This study is descriptive in nature. The researcher has collected information from published books, journal papers, newspapers, articles, etc.

\subsection{Modern Trends in Work Life Balance}

Organizations have started implementing many work-life balance strategies. They offer child care, elder care, flexible work schedules, job sharing and employee assistance programmes as alternatives for work balance arrangements [45].

These measures help the employer to retain high potential employees and efficient workforce. The modern industrial establishments have started the following trends.

- Maternity Leave: Increase in the number of women workforce and the issues related to work-life balance various policies like Maternity Benefit Act 1961 which provided 12 weeks(three months) paid leave to all women employees has been amended in 2016 and increased to 26 weeks (six months) [6].

- Paternity Leave: Central Civil Services, Leave Rules 43-A grants Paternity leave to male government employees' up to a period of 15 days during the childbirth [7].

- Parental leave: Parental leave is availed by parents to look after a young child or to make arrangements for the child's welfare. Parents can also make use of this leave to spend more time with their children and strike a balance 
between work and personal family commitments.

- Part-time work: Employees who prefer to work part-time for various reasons such as attending family, studying, pursuing personal hobbies and many others can give importance to priorities other than work. Those wishing to work on part-time basis may benefit from this policy.

- Family leave: this facility helps the employees to take leave for the illness of the immediate family members (spouse, parent or child) on the provision of the medical certificate here every employee has a right to avail family leave which cannot be postponed or refused.

- Teleworking: This is a work arrangement where an employee may be authorized to carry out part of their activities from home on a regular basis over a period of time. The organization or the employee may propose teleworking but this does not give an automatic right to telework.

- Unpaid leave: At some point, if an employee wishes to take a break from their career to give importance to other personal or professional priorities, organizations may recognize through unpaid leave.

- Time off to care for sick children: Taking time off to look after the child or to fetch the sick child from school or crèche is an arrangement that can help parents to maintain work life balance.

- Flexi-time: This is a system that allows an employee to choose his own timing for starting and finishing work with the range of available hours subject to achieving total daily, weekly or monthly hours. It is a beneficial opportunity given by organizations to its employees of flexible hours provided they are at work during the core hours.

- Crèche facilities: some of the organizations provide their own crèche where the employees can enroll their pre-school children. This will end the dilemma that forces women to choose between work and children.

\section{WORK LIFE BALANCE INITIATIVES IN INDIAN ORGANIZATIONS :}

As a part of the work environment, organizations are now making great efforts to provide caring and engaging environment. A study consisting of 20 Fortune 500 companies has found that $28 \%$ of the men and $53 \%$ of the women reported inability to concentrate at work due to work family stress. This reveals that more than half of women and one-third of men are affected by work-family stress. This is the result of the rapid increase in the number of dual earners creating work-life conflict [8]. In Mind Tree and Pepsi Company, employee engagement strategies are eagerly helping them to maintain better work-life balance. At Marico Company, employees depending on their roles have the flexibility to decide the timings of their work after the discussion with their supervisor. The company does not maintain any system for measuring hours of work or the attendance registers. Citi India has recently introduced a policy that allows employees (depending on their role) to work from home for two days in a month. Employees have the freedom to opt for flexi- time and remote working. Concierge service has been recently introduced by the company within the office premises to help employees to free up valuable time. It is even known for its contingency leave policy where the employees can seek oral leave approval from the supervisor. The record of such leave is not maintained for a period of four days [9]. Pepsi Co India has started a concept of healthy and free breakfast with oats, fruits, Upma, Poha etc. This has benefited the young unmarried staying alone and newly married employees. Pepsi Co has tied with Ida and Intelliots for providing day care facilities in Gurgaon, Mumbai, Hyderabad, and Chandīgarh. Here employees can avail huge discount OF Rs.40,000 - 50,000 along with other benefits. Dabur India is concentrating on the health and fitness of employees realizing that a healthy employee is a productive employee. Coca-Cola encourages employees to enroll in healthy living programmes like tennis, gym, Aerobics, Yoga by funding up to $50 \%$ of the expenses incurred on equipment and memberships. Mahindra \& Mahindra encourages employees to go for medical check-ups by having tie-ups with diagnostic center and Stepathlon Lifestyle. Raychem RPG provides 
101 services such as maintenance of electronics, parent care to getting laundry done to pet care which employees to enjoy their free time and weekends. Infosys Technologies' provides wellness initiative Health Assessment Lifestyle Enrichment (HALE). Wipro also offers wellness initiate to employees to reduce stress. Johnson and Johnson India in 2002 started Women's Leadership Initiative (WLI) to attract women leaders in the company. The company also created awareness on health issues, support to orphans, street children, tribal girls, maternity and gynecological care to women. Procter \& Gamble India has reduced work schedules and has offered employees to work from home helping boost up employee productivity and maintain work-life balance [10].

Intel India provides work environment solutions to reduce work and personal challenges and enhance Intel's great place to work value. In addition to flexible working hours, five days working is also offered. It also provides Hospitalization Insurance Policy with reimbursement of hospital expenses incurred by an employee and their nominated dependents who are covered under a floater policy (Rs.500,000 p.a) Intel also pays the premium for employees (100\%) and dependents (80\%). Hospitalization Insurance covers maternity insurance for employees and their spouse. In the case of pregnancy, Intel gives each employee paid maternity leave(84 days). Depending upon the years of service15 days for first two years and 20 days for more than two years) annual leave facilities are given to employees excluding 12 paid public holidays in a year. Under Business Traveler Medical plan, Intel provides medical coverage to its employees (full time and part-time employees) when they are on business travels outside India (90 days). In the event of the insured employee's death, Intel ensures payment of lump sum to the deceased employee's legal heir. Intel pays the 100\% premium. Other benefits include flexible work hours, alternate work schedules, compressed work weeks, home office, telecommuting, part time employment, resource and referral services, childcare care assistance, health benefits and wellness benefits. IBM's policy says that organization is very serious about helping employees to achieve career balance. IBM India provides to its employee's options like working from home, flexible workweek schedules, parttime employment, family counselling and absence leave. Provisions include reimbursement, recreational activities, global opportunities, and clubs, helping employees with life events (marriage, taking career break).This helps IBM to attract, motivate and retain the best talent. TATA Group, being one of the oldest group and respected business organization is also known as most people focused company. It is also known to have high scores on welfare parameters. Here work-life balance initiatives are tailored as per different strata of employees. For the workforce in manufacturing plant, company has introduced adult education programmes and family life education. Crèche facility is provided to help the female employees. Tata Consultancy Services (TCS) an emerging new economy organization incorporated under Tata group has a pool of educated executive class employees. The company provides to its employee's options to work flexi time with certain compulsory core hours of work and provisions to work for fiveday. Most prominently TCS conducts regular seminars on better living, nutrition and stress management. Understanding and realizing the impact of long working hours, desk-bound jobs and extensive travel that result in a work-life imbalance of many employees, the company has encouraged the formation of groups with similar interests to come together and conduct various activities apart from routine work. Zensar Technologies provides crèche facility and child care arrangements to its facilities. The informal meeting is arrangement where associates can meet their seniors and discuss anything. Zensar has a facility called Madat online a 24/7 service available for employees to take care of some of their personal day to day activities such as drawing cash, dropping cheques, pay telephone bills and school fees of employees children. Information services such as housing and education facilities for children. Zensar Technologies organizes stress management programmes. Social events such as family day 
and fun days at work are also organized regularly. This shows Indian Organizations have realized the need for work-life balance and are taking initiative to provide a work-family friendly environment to their employees [11].

\section{CHALLENGES AND PROSPECTS FOR INDIAN ORGANIZATIONS :}

Though Indian Organizations are trying their best to provide work life balance programmes, many organizations consider it as a burden and not a strategic decision. In the present situation where the organizations are going global reducing cost or cost cutting is the biggest challenge for Human Resource Managers. Policy makers feel that work-life balance initiatives will increase the financial burden. This increase the budget will make it difficult for them to survive in this competitive global market. In India where more and more women are entering into workforce statutory policies such as maternity benefit and leave is common but work-life arrangements such as flexi time, part time work and work from home are sporadic and are discretionary in nature. Moreover, policies and practices like paternity leave, telecommuting, child care leave, health assistance programmes, parental care leave, child care centers, stress release programmes and training are yet to be considered as a strategic decision by the organizations. Indian organizations have an advantage of the young, energetic and efficient workforce. But the attrition rate of employees in organized sector in India was $26.9 \%$ in 2013, highest attrition rate globally [12]. Human resource department has to efficiently utilize these resources by exploring some innovative policies and practices. The McCrindle's Research study of 3000 Australians reveals that work-life balance is the major factor for employee attraction and retention that can be ranked above salary. Many researchers have shown that work and family are not separate but influence each other [13]. These work-life balance practices increase the performance of employees and motivate them to be more committed towards the job. Work-life balance provides opportunity make better use of employees free time and to fulfill other commitments and activities along with work. More importantly, it helps to reduce employee's mental stress and results in job satisfaction. Therefore the organizations should recognize the value and contributions of work-life balance practices on employees and organizations performance.

\section{CONCLUSION :}

The work-Life Balance for women employees is a buzz word for today's organizations. Various strategies are developed and implemented by the organizations. Women employees are also expected to design and develop good lifestyle practices to balance work and family demands. These coping strategies will help the employer and the employees to deal with the problems and the issues of work life balance. The work-life balance brings peace and happiness in the lives of the employees. It acts as a survival strategy for the employer in the tough competitive market as it adds value to the organizational work culture and also family life. Organizations have realized the power of work-life balance strategies and are trying their best to implement it successfully. This revolutionary awareness will help organizations to retain and use the potentials of the employees to the fullest.

\section{REFERENCES :}

[1] Noronha, S., \& Aithal, P. S. (2016). Glass Ceiling - A Silent Barrier for Women in Highly Advanced and Humanistic Society. IRA-International Journal of Management \& Social Sciences, 5(3), 455-466.

[2] Clark SC,(2000). Work/Family Border Theory: A New Theory of Work/Family Balance. Human Relations, 53(6): 747-770.

[3] Glass, J. L., \& Estes, S. B.(1997). The Family responsive workplace. Annual Review of Sociology, 23(1), 289-313.

[4] Dalcos, S. M., \& Daley, D. (2009). Work pressure, workplace social resources and work-family conflict: The tale of two sectors. International Journal of Stress Management, 16(4), 291-311.

[5] Hobsor, C. J., Delunas, L., \& Kelsic, D. (2001). Compelling evidence for the Need 
for Corporate Work/Life Balance Initiatives: Results from a national survey of stressful life-events. Journal of Employment Counseling, 4(8), 38-44.

[6] Maternity Benefit (Amendment) Act, 2017, Ministry of Law and Justice, New Delhi, $28^{\text {th }}$ March, 2017.

[7] Central Civil Services, Paternity Leave, CCS (Leave) Rules, Rule 43-A, central government staff news posted on Sunday, November 25, 2012.

[8] Francene Sussner Rodgers, (1992). When the Business Case Is Common Sense: Coming to Terms with America's Family Challenge, autumn 1992, ACA Journal.

[9] Manavi Pathak (2014), Psychology at work, Making managers responsible. www.humancapitalonline.com.

[10] Barik, P., \& Pandey, B. (2016) Work-life Balance a Strategic Human Resource Policies and Practices followed by Indian Organizations. IRA-International Journal of Management \& Social Sciences, 5(3), 427435.

[11] Andukuri Raj Shravanthi, Sagar Deshmukh, N. Deepa (2013),Work Life Balance of Women in India. International Journal of Research in Management Sciences, 1(1) 50.

[12] Biswas S.(2013). Attrition in India to top world charts in 2013; one in four employees to change jobs www.economictime s.indiatimes. com/jobs/attrition-in-india-totop-world-charts-in-2013, The economic times, June 07, 2013

[13] Greenhaus, J.H. and Powell, G.N.(2006). The Academy of Management Review, 31(1), 72-92. 